\title{
Analysis of reasons for discarding blood and blood components in a blood bank of tertiary care hospital in central India: A prospective study
}

\begin{abstract}
Background: Many modern surgical procedures could not be carried out without the use of blood. There are no substitutes for human blood. Thus, proper utilization of blood is necessary with minimal wasting. Materials and Methods: A total of 10,582 donors donated blood during the study period of 19 months in blood bank of a tertiary care hospital, central India from $1^{\text {st }}$ of November 2009 to $31^{\text {st }}$ May 2011 , which were screened. Results: A total of 346 whole blood bags were discarded. Out of these 346 blood bags, 257 (74.30\%) were discarded because of seropositivity for transfusion transmissible infectious diseases. A total of 542 blood components were discarded against 3702 blood components prepared during the study period. Among blood components discarded, most common units were platelets. The most common cause of discarding the blood components was expiry of date due to nonutilization $(87.00 \%)$. Conclusion: A properly conducted donor interview, notification of permanently deferred donors will help in discarding less number of bags from collected units. Similarly, properly implemented blood transfusion policies will also help in discarding less number of blood bags due to expiry. These discarded bags, because they are unutilized are both financially as well as socially harmful to the blood bank.
\end{abstract}

Key words: Blood bags, discard, expired blood and blood components

\section{Alok Kumar, Satish M Sharma, Narayan Shyamrao Ingole, Nitin Gangane}

Department of Pathology, Mahatma Gandhi Institute of Medical Sciences, Sevagram, Wardha, Maharashtra, India

Address for the Correspondence: Dr. Alok Kumar, Assistant Professor, Department of Pathology, Government Medical College, Jagdalpur, Chhattisgarh, India. E-mail: alokkrlkr@gmail.com

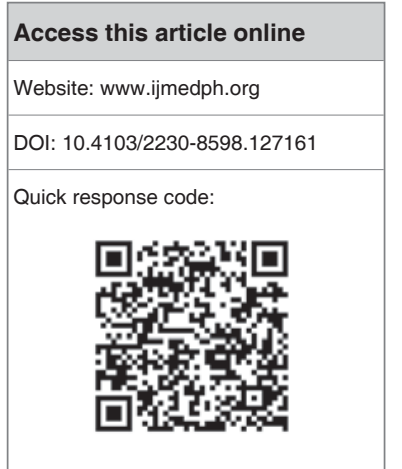

\section{INTRODUCTION}

Today, many modern surgical procedures could not be carried out without the use of blood and there is no substitutes for human blood. ${ }^{[1,2]}$ It has been estimated that one-third of all patients admitted to intensive care units in the developed world receive a blood transfusion. ${ }^{[3]}$ So each unit of blood is precious and utilized judiciously with minimal wasting. By analyzing the data and the reason for the discards, the blood transfusion services can develop plans to improve performance through education and training of staff and introducing new measures in order to minimize the number of discarded blood to a reasonable rate. ${ }^{[4]}$ The aim of this study was to find out the reasons for discarding blood bags so that they could be utilized judiciously with minimal wasting.

\section{MATERIALS AND METHODS}

\section{Study design}

The study was carried out in the blood bank of a tertiary care hospital in central India over a period of 19 months from $1^{\text {st }}$ of November 2009 to $31^{\text {st }}$ May 2011.

\section{Type of study}

It was a prospective study.

\section{Inclusion criteria}

Blood donors, fulfilling World Health Organization criteria for donor selection, were included in this study after medical history, brief clinical examination by the medical officer. The donors were either voluntary or replacement. Replacement donors were either relatives or friends of the patients. 


\section{Data analysis}

Blood bags included during this period, were screened for transfusion transmissible infections (TTIs). The blood bags, which were seroreactive (seropositive) were discarded. The blood bags, which were expired because of non-utilization, were discarded. Less amount of blood collected from the donors because of any reasons, including donor's reactions was discarded. Blood showing any changes of either hemolysis or turbidity were also discarded.

\section{RESULTS}

Among total donors in the blood bank, 97.05\% were male and $2.95 \%$ were female. Almost $78 \%$ were voluntary donors and $22 \%$ were replacement donors. Among voluntary donors $96.24 \%$ were male and $3.76 \%$ were female donors as shown in Table 1.

Out of total 10,582 blood bags which were collected from donors during the study period, 346 (3.25\%) of whole blood bags were discarded. Out of these 346 bags, approximately $74.30 \%$ were discarded because of seropositivity for TTIs. Among infectious diseases, hepatitis B infection was the most common cause for discarding as shown in [Table 2].

Amongst whole blood bags discarded, seropositivity for TTIs were the most common cause followed by expiry of date due to nonutilization (11.84\%), others cause include yellowish discoloration of plasma, signs of hemolysis noted in blood bags, issued blood bags to the patients but not used as shown in Table 3.

A total of 542 blood components were discarded against 3702 blood components prepared during the study period. The most common blood components were discarded were platelets followed by fresh frozen plasma (FFP)-as mentioned in Table 4.

A total of 542 blood components were discarded in which the most common cause was expiry of blood components, constituted $87.00 \%$ followed by seropositive for transfusion transmitted diseases, constituted $8.00 \%$ as shown in Table 5 .

\section{DISCUSSION}

In a study done by Thakare et al. ${ }^{[5]}$ it was observed that $3.58 \%$ of blood bags were discarded. The main reason of the discarding these blood bags was the positivity for different transmissible diseases (TTIs) constituting $68.86 \%$ followed by other reasons $(31.13 \%)$. Among the units discarded, $49.82 \%$ were positive for hepatitis B surface antigen ( $\mathrm{HBs} \mathrm{Ag}$ ), 10\% for human immunodeficiency virus (HIV) and $8.97 \%$ for hepatitis C virus (HCV) while no unit was positive for Venereal Disease Research Laboratory.

In a study done by Deb et al. ${ }^{[6]}$ it was observed that an average 292 (14.61\%) bags from the total collection were discarded. Of the 292 units discarded, 242 units were due to non-utilization.

In another study done at Choithram Hospital and Research Center, Indore, India by Chitnis et al. ${ }^{[7]}$ it was observed that approximately

$\begin{aligned} & \text { Table 1: Source of blood bags as per sex and } \\
& \text { type of donors }\end{aligned}$
\begin{tabular}{lccc}
\hline Types of donors & Male (\%) & Female (\%) & Total donors (\%) \\
\hline $\begin{array}{l}\text { Voluntary donors } \\
\text { Replacement }\end{array}$ & $2347(96.24)$ & $310(3.76)$ & $8232(77.79)$ \\
donors & $03(0.10)$ & $2350(22.21)$ \\
Total & $10269(97.05)$ & $313(2.95)$ & $10582(100)$ \\
\hline
\end{tabular}

Table 2: Analysis of discarded whole blood bags
(due to seroreactive cases)
\begin{tabular}{lllll}
\hline $\begin{array}{c}\text { Total } \\
\text { discarded (\%) }\end{array}$ & HIV (\%) & HBs Ag (\%) & HCV (\%) & VDRL (\%) \\
\hline $257(100)$ & $51(19.84)$ & $179(69.64)$ & $21(8.18)$ & $6(2.34)$ \\
\hline
\end{tabular}

HIV = Human immunodeficiency virus, $\mathrm{HBs} \mathrm{Ag}=$ Hepatitis B surface antigen; $\mathrm{HCV}=$ Hepatitis C virus, VDRL = Venereal Disease Research Laboratory

\begin{tabular}{|c|c|c|c|c|}
\hline $\begin{array}{c}\text { Total discarded } \\
\text { bags (\%) }\end{array}$ & $\begin{array}{c}\text { Seropositive } \\
\text { (\%) }\end{array}$ & $\begin{array}{c}\text { Date } \\
\text { expired (\%) }\end{array}$ & $\begin{array}{c}\text { Less } \\
\text { volume (\%) }\end{array}$ & $\begin{array}{l}\text { Others } \\
(\%)\end{array}$ \\
\hline $346(100)$ & $257(74.30)$ & $41(11.84)$ & $18(5.20)$ & $30(8.66)$ \\
\hline
\end{tabular}

\begin{tabular}{|c|c|c|c|}
\hline $\begin{array}{l}\text { Blood } \\
\text { components }\end{array}$ & $\begin{array}{c}\text { No. of blood } \\
\text { components prepared }\end{array}$ & $\begin{array}{c}\text { No. of units } \\
\text { discarded }\end{array}$ & $\begin{array}{l}\text { Discarded } \\
\text { rate (\%) }\end{array}$ \\
\hline Packed red cells & 1296 & 36 & 2.78 \\
\hline Platelets & 1110 & 412 & 37.11 \\
\hline $\begin{array}{l}\text { Fresh frozen } \\
\text { plasma }\end{array}$ & 1296 & 94 & 7.25 \\
\hline Total & 3702 & 542 & 14.64 \\
\hline
\end{tabular}

\begin{tabular}{|c|c|c|c|}
\hline \multirow[t]{2}{*}{ Blood components } & \multicolumn{3}{|c|}{$\begin{array}{l}\text { Reasons for discarding blood } \\
\text { components }\end{array}$} \\
\hline & Expired & Leakage & Seropositive for TTIs \\
\hline Platelets & 401 & - & 11 \\
\hline Packed red cells & 20 & - & 16 \\
\hline Fresh frozen plasma & 51 & 27 & 16 \\
\hline Total (542) & 472 & 27 & 43 \\
\hline
\end{tabular}

TTIs = Transfusion transmissible infections

(8.9-10\%) of blood bags were discarded (approximately 80 blood bags were discarded monthly against a total of 800-900 units collection) as reactive for $\mathrm{HIV} / \mathrm{HBs} \mathrm{Ag} / \mathrm{HCV}$ or contamination/ reactions to recipients and expired units.

In a study done by Gauravi et al..$^{[8]}$ in Saurashtra region of Gujarat, it was found that in 2008, 226 blood bags were discarded against 7882 blood bags collected due to seropositive for T'TIs diseases. In 2009, 178 blood bags were discarded due to seropositive for infectious diseases against total 8141 blood bags collected and in 2010, 212 blood bags were discarded against 9441 blood bags collected due to seropositive for T'TIs diseases. 
In a study done by Morish et al. ${ }^{[4]}$ in National blood center, Kuala Lumpur, a total of 390,634 whole blood and blood components units were prepared in 2007 in National Blood Center. Of these 8968 (2.3\%) units were discarded. Platelet concentrate scored the highest at $6 \%$ when compared with the other blood components. The discarded rates of whole blood and packed red blood cells (RBCs) were $3.7 \%$ and $0.6 \%$, respectively. The reasons behind the discard of whole blood can be attributed to procedures carried out during the collection process. The leakage was the second cause of discarded blood and its components, which represented $26 \%$ of discarded blood. The frozen blood components that consist of $43 \%$ and $27 \%$ of discarded FFP and cryoprecipitate, respectively, were due to the leakage. $25 \%$ (2208) of discarded blood were wasted because of gross lipemic blood components.

A large-scale study conducted in 17 blood centers in 10 European countries from 2000 to 2002 reported that the mean platelet discard rates for the 3 years were between $6.7 \%$ and $25 \%$. However, the annual mean discard rates from 2000 to 2004 remains at 13\%. The discarded platelets included all platelet units, which were damaged during processing regardless of the preparation method as well as those that expired. ${ }^{[9]}$

In the same European centers, the mean for packed RBC discard rate was $4.5 \%$, varying annually from $0.2 \%$ to $7.7 \% .^{[10]}$

The current study showed that the FFP and RBC discard rates were comparable with the Novis et al. study in USA, which reported that the discard rates of FFP ranged from $2 \%$ to $2.5 \%$ and RBC ranged from $0.1 \%$ to $0.7 \%$ in 1639 hospitals. ${ }^{[9,11]}$

\section{CONCLUSION}

As compared with these studies, it was observed that lesser number of blood bags was discarded in our blood bank. It was mostly because of positivity for different transmissible diseases (TTIs). Among blood components discarded, most commonly units were platelets. The most common cause of discarding the blood components was expiry of date due to non-utilization.
A properly conducted donor interview, notification of permanently deferred donors will help in discarding less number of bags from collected units.

Similarly, properly implemented blood transfusion policies will also help in discarding less number of blood bags due to expiry. These discarded bags, because they are unutilized are both financially as well as socially harmful to the blood bank.

\section{REFERENCES}

1. Zmijewski CM, Walter EH. Blood Banking Science. New York: Appleton Century Croft; 1982.

2. An Action Plan for Blood Safety. New Delhi: National AIDS Control Organization, Ministry of Health and Family Welfare Government of India, MOHFW; 2003.

3. Saxena S, Weiner JM, Rabinowitz A, Fridey J, Shulman IA, Carmel R. Transfusion practice in medical patients. Arch Intern Med 1993;153:2575-80.

4. Morish M, Ayob Y, Naim N, Salman H, Muhamad NA, Yusoff NM. Quality indicators for discarding blood in the National Blood Center, Kuala Lumpur. Asian J Transfus Sci 2012;6:19-23.

5. Thakare MM, Dixit JV, Goel NK. Reasons for discarding blood from blood bank of Government Medical College, Aurangabad. Asian J Transfus Sci 2011;5:59-60.

6. Deb P, Swarup D, Singh MM. Two corps blood supply unit, 56 APO audit of blood requisition. Med J Armed Forces India 2001;57:35-8.

7. Chitnis V, Vaidya K, Chitnis DS. Biomedical waste in laboratory medicine: Audit and management. Indian J Med Microbiol 2005;23:6-13.

8. Gauravi D, Agravat A, Krupal MP. Seroprevalence of HIV, HBV, HCV and syphilis in blood donors in Saurashtra Region of Gujarat: Declining trends over a period of 31/2 years. Online J Health Allied Sci 2012;11:5.

9. Veihola M, Aroviita P, Linna M, Sintonen H, Kekomäki R. Variation of platelet production and discard rates in 17 blood centers representing 10 European countries from 2000 to 2002. Transfusion 2006;46:991-5.

10. Veihola M. Technical Efficiency of Blood Component Preparation in Blood Centres of 10 European Countries. Academic Dissertation. Finland: Department of Public Health, Faculty of Medicine University of Helsinki; 2008. p. 5.

11. Novis DA, Renner S, Friedberg RC, Walsh MK, Saladino AJ. Quality indicators of fresh frozen plasma and platelet utilization. Arch Pathol Lab Med 2002;126:527-32.

How to cite this article: Kumar A, Sharma SM, Ingole NS, Gangane $\mathrm{N}$. Analysis of reasons for discarding blood and blood components in a blood bank of tertiary care hospital in central India: A prospective study. Int J Med Public Health 2014;4:72-4.

Source of Support: Nil, Conflict of Interest: None declared. 